\title{
Búcsú NOSEK JÁNOS biológustól (1949-2020)
}

\author{
BAKONYI GÁBOR ${ }^{1 *}$ és VÁSÁRHELYI TAMÁS ${ }^{2}$ \\ ${ }^{1}$ Magyar Agrár- és Élettudományi Egyetem, Állattani és Ökológiai Tanszék, 2100 Gödöllő, Páter K. u. 1. \\ ${ }^{2} 1125$ Budapest, Diós árok 16/II. \\ *E-mail: gaborbakonyi11@gmail.hu
}

2020-ban elhunyt kedves barátunk és munkatársunk, akihez sok személyes és szakmai kapcsolatunk kötött. Öt már nem hozza vissza semmi, de emlékét szeretnénk megőrizni a hazai zoológus-társadalom számára az alábbi írással.

Édesapja, NOSEK JÁNOS, Erdélyböl települt át Budapestre a háború előtt. Több nyelven beszélő, elismert hangmérnök volt a Magyar Mozi- és Videofilmgyárban. Édesanyja, DEIXLER ERZSÉBET, a Fővárosi Operettszínház jelmezmühelyének vezetőjeként ment nyugdíjba. JÁNOS egyedüli gyermekként nőtt fel.

Általános iskoláját a IX. kerületben, a középiskolát az V. kerületi Eötvös József Gimnázium német nyelvtagozatán végezte el. Már ekkor megmutatkozott a természettudományok iránti érdeklődése.

Fiatal éveiről HAJDÚ JÁNOS, az MTA Uppsalában élő tiszteletbeli tagja írt levelet. Érdemes hosszabban is idézni belöle, mert a kor jellemzésén túl kiderül, hogyan bontakozott ki a későbbi, sokféle irányban nyitott biológus kutató, és egyben azt is látjuk, milyen nagy szerepe van a tanároknak a fogékony gyermekek és fiatalok életpályájában. „A Mester utcai Fiúiskolától egészen érettségiig padtársak voltunk, és körlettársak 11 hónapos katonai szolgálatunk alatt is, Hódmezövásárhelyen. Mindketten vonzódtunk a természettudományokhoz és a matematikához, és gyorsan összebarátkoztunk... Hetedikes korunkban mindketten irásbeli engedélyt kaptunk a Magyar Nemzeti Múzeum igazgatójától, hogy a természettudományi kiállitásokban szabadon fényképezhessünk. A filmeket magunk hivtuk elö és magunk készítettük a nagyitásokat az iskola fotószakkörében. A múzeum ásvány-és kristálytani kiállitása lenyügözö volt. A röntgen diffrakció leírása különösen jó volt (én még ma is ezzel foglalkozom). A legközelebbi iskolai tüdöszüréskor elkértünk egy szép nagy kvarc kristályt, hogy megnézzük, milyen is ez a röntgen diffrakció a valóságban. A kristályt 'ólomkesztyüvel' tartottuk a röntgen masinában, de semmi diffrakciót nem láttunk. Abszolút semmit, csak a kristály körvonalait. A kristály túl nagy volt, és elnyelte a röntgensugarakat, de erre csak később, a gimnáziumban jöttünk rá.

Az Eötvös József Gimnázium német szakán nagy hatású tanárok formáltak minket... Nagyon jó tanáraink voltak. Azt hiszem talán két dolog játszott itt össze. Az, hogy a tanárokra akkoriban még mindenki fölnézett Magyarországon, és hogy sok tanárunk lehetett volna sokkal magasabb állásban pl. egyetemeken, kórházakban, kutatóintézetekben, de a rendszer nem engedte az osztályidegent és a hagyományos értelmiséget tovább lépni. A tanítói/tanári pálya viszonylag szabad maradt az ilyen 'elemek' számára. Évtizedekkel 
később, amikor professzor lettem Stanfordban, láttam, hogy ezt milyen jól lehet tudatosan is kihasználni: Az egyetem összes Nobel dijasa az elsö éves diákokat tanitotta, mert így lehet a rakétát begyújtani a diákokban. Velünk is ez történt a Ferencvárosban - valamivel szerényebben.

Nosek Jancsi soha nem kereste a kisutakat, soha nem volt 'szemes'. Mindent a legkomolyabban és odaadással csinált. Nem tolakodott."

A gimnázium évkönyvének 1967-es kötetéből megtudjuk, hogy ők ketten már 1964-ben részt vettek a VII. Országos Biológiai Kongresszuson, 1965-ben, a VIII. kongresszuson pedig már mint hozzászólók is. A szakkörrel látogatták meg a tihanyi Halbiológiai Intézetet, Alsógödön a Magyar Dunakutató Állomást, a Természettudományi Múzeum Öslény- és Állattárát, és számos egyéb intézményt is. JÁNOS, a biológiai szakkör vezetője, szervezett szakköri biológiai versenyt és nyert tanulmányi versenyt is.

Ami jót, indítást tanáraitól kapott, azt később más gyerekeknek adta vissza. 1986-ban szakvezetőként bekapcsolódott a Magyar Madártani és Természetvédelmi Egyesület Börzsönyi Helyi Csoportja által alapított Börzsönyi Természetvédelmi Tábor munkájába. A Vizi világ c. programot tartotta 11-14 éves iskolások részére. Ezt a tevékenységét töretlen lelkesedéssel több, mint harminc évig végezte. A gyerekekkel nemcsak a környező tavi és pataki élőlényeket, föképpen makrogerincteleneket ismertette meg (helyszíni gyüjtések és korábban begyüjtött minták alapján), hanem - ami jellemzője volt - komoly elméleti ismereteket is átadott a víz tulajdonságairól és a vízi ökoszisztémák jellemzőiről az általa készített szemléltető anyag segítségével. Része lehetett abban, hogy több gyerek is természettudományos pályát választott a későbbiekben.

FRITZNÉ DR. TERBE ERIKA (táborvezető) így osztotta meg halálhírét a táborok szervezőivel: „Nehéz most bármit is hozzátenni a hírhez, hiszen akik ismertük, egyre gondolunk. Évtizedekig elválaszthatatlan volt a tábortól, csakúgy, mint Edit néni [JÁNOS felesége, MOLNÁR EDIT (a szerk.)]. Amikor már nem tudott programot vállalni, akkor is velünk volt, hiszen sziporkázó, csipkelődő humorát, sommás megjegyzéseit gyakran emlegettük, már életében legendává vált. Számos közös élményt örzünk emlékeinkben, és tudjátok, csak az hal meg, akit elfelejtenek, és örökké él, akit szeretnek. Az utolsó közös emlékek, a nyári látogatás, majd az öszi találkozó a 'régi' Jancsi bácsit idézte. Ezt a képet örizzük meg szivïnkben!"”

NOSEK JÁNOS tanulmányai során 1967-ben előfelvételt nyert az ELTE biológus szakára, és a kor divatja szerint egyéves sorkatonai szolgálatot teljesített, későbbi évfolyamtársaival egy csapatban, akikkel biológiai önképzőkör-félét szerveztek tudásuk szinten tartása érdekében. Egyetemi évei alatt a Fővárosi Állatkertben, PÉNZES BETHEN irányításával, a halivadék táplálására szolgáló sóféreg tenyésztésével foglalkozott. ${ }^{1}$ Ebből a témakörből egy TDK-dolgozat is született. Érdekelte az egyetemi oktatás sikeressége, minősége is. Évfolyamtársaival írott - érett - cikkük tanúskodik erről. ${ }^{2}$

Szakmai életpályája egyetlen munkahelyhez kötődött. Miután okleveles biológusként végzett az ELTE Természettudományi Karán (1973), ősztől Alsógödön, az MTA Magyar

\footnotetext{
${ }^{1}$ ifj. NoseK J. 1971. A sóféreg tömeges tenyésztése. Halászat, XVII.(64.)(6): 182-183.

${ }^{2}$ BÁrdos Gy., HERMAN J., IFJ. NOSEK J. \& KISS J. 1971. Reform vagy az oktatás forradalma. Felsőoktatási Szemle 20: 234-239.
} 
Duna-kutató Állomáson (jelenleg Eötvös Loránd Kutatási Hálózat, Ökológiai Kutatóközpont, Vízi Ökológiai Intézet) kezdett el dolgozni, mint tudományos segédmunkatárs. Ebben az intézetben volt kutató nyugdíjazásáig (2009). Mentora és atyai jóbarátja, a neves kvantitatív ökológus, PRÉCSÉNYI ISTVÁN hatására, és JUHÁSZ-NAGY PÁL elképzeléseit megismerve választotta egyetemi doktori értekezése témáját. Az akkor még kevéssé kutatott elméleti ökológiai témakörből írta értekezését, amelyben a diverzitás függését vizsgálta térfolyamatokban. Disszertációját - Néhány diverzitás-függvény összehasonlító vizsgálata különbözó mintavételi feltételek mellett, botanikai objektumon - „summa cum laude” minősítéssel védte meg 1976-ban.

Pályája elején a Duna medrének élőlénybevonatát kezdte vizsgálni OERTEL NÁNDORral együtt, akivel a szakmai és baráti kapcsolata mindvégig megmaradt. Jól emlékezünk azokra a vizsgálataikra, amelyek keretében kihelyezett mesterséges aljzatokon követték nyomon a betelepülő élőlényközösségek változásait.

Ebben az időben alakult ki szoros szakmai és baráti kapcsolata a GATE Állattani és Ökológiai Tanszékének (jelenleg MATE, Állattani és Ökológiai Tanszék) dolgozóival. A hetvenes-nyolcvanas években füves területek nitrogénforgalmát kutatták (TECE Projekt). Ebben a vizsgálatban a terepen is sokat dolgoztak együtt (jómagamat - BG - is beleértve), de kiváló statisztikai és modellezési képzettsége alapján döntő része volt az eredmények kiértékelésében. Ez a kapcsolat a tanszékkel később folyamatos közös oktatási-kutatási tevékenységben nyilvánult meg. Elsősorban kiemelendő, hogy 19 éven keresztül társtárgyfelelősként vezette a „Biogeográfia” című tantárgyat. Emellett azonban számos alkalommal vett részt a graduális (ökológia) és prosztgraduális (környezetvédelmi ökológia) tantárgyak oktatásában, mint meghívott előadó. Elsősorban a rendszerelmélet ökológiai vonatkozásaival kapcsolatos kérdésköröket oktatta. Ez a modern és rendkívül fontos témakör nélküle nem lenne jelen kellő súllyal az oktatásunkban. Rendszeresen vállalt konzulensi, opponensi feladatokat, továbbá bíráló, valamint bizottsági tag volt a TDK-konferenciákon és minden évben tagja valamelyik záróvizsga-bizottságnak is. Munkájának elismeréseképpen címzetes egyetemi docenssé nevezték ki a Szent István Egyetem Állattani és Állatökológiai Tanszékére (2001).

Évtizedeken keresztül foglalkozott a Duna különböző vízterületein előforduló egysejtűés perifiton- (bevonatot alkotó) együttesek szerkezetvizsgálatával, különös tekintettel a változásokat kiváltó és befolyásoló környezeti tényezőkre. Sok kutatóval dolgozott együtt komolyabb projekteken a hidrobiológia területén (a már említett OERTEL NÁNDORon kívül, aki állandó kutatótársa volt): V. KOZMA ERZSÉBETtel (vízkémia), CSUTORNÉ BERECZKY MAgdolnÁval (Ciliata), ANDRIKOVICS SÁNDORral (Ephemeroptera, Plecoptera, Trichoptera), CSABAI ZOLTÁNnal (Coleoptera), BÓDIS ERIKÁval (Mollusca), TóTH BENCÉvel (vizek szervesanyag-forgalma), valamint e cikk szerzőivel (Heteroptera). Részt vett a Balaton gerinctelen állatainak vizsgálatában (PONYI JENŐvel). A vízi makrogerinctelenek különösen érdekelték. Szívesen járt terepre, szeretett gyüjteni, fényképezni, részt vett az anyagok határozásában is, de a kvantitatív adatfeldolgozásban és adatkiértékelésben volt igazán nagy mester. 


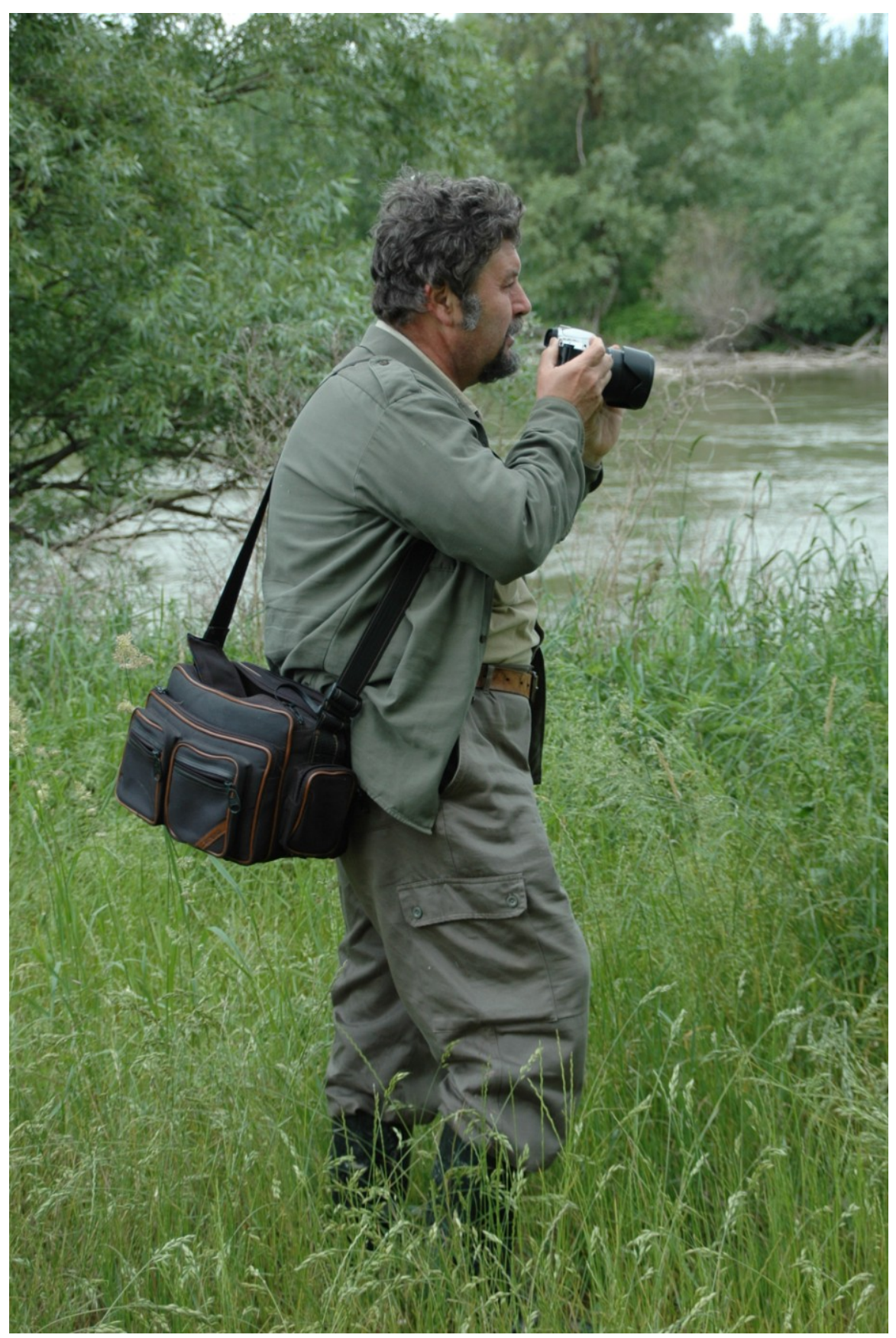

1. ábra. NOSEK JÁNOS (1949-2020) (OERTEL NÁNDOR felvétele).

Figure 1. JÁNOS NOSEK (1949-2020) (Photo: NÁNDOR OERTEL). 
NOSEK JÁNOS, 1993-2004 között mint az ország egyetlen ökológiai kutatóintézetének igazgatóhelyettese, jelentős hazai és nemzetközi ismertséggel rendelkezett. Több kutatási pályázat vezetője vagy résztvevője volt. Összes megjelent tudományos publikációinak száma 115. Angol és német nyelvtudásának köszönhetően számos szakkönyvet fordított magyar nyelvre. Ezzel nagy szolgálatot tett a biológusoknak, mert abban az időben kevesen bírták magas szinten az említett nyelveket.

Egyesületi és testületi tagságai közül kiemelendő az MTA Ökológiai, Környezetbiológiai, Biometriai és Biomatematikai Bizottságaiban és a Magyar Hidrológiai Társaságban való részvétele. Tagja volt a Nemzetközi Limnológiai Szövetségnek (SIL) és a Nemzetközi Duna-kutató Munkaközösségnek (IAD), a VITÁLIS SÁNDOR Szakirodalmi Nívódíj Bizottságnak is. Tudományszervezői tevékenysége jelentős, több nemzetközi és két hazai konferencia szervezője vagy szervezőbizottsági tagja, a MAVIGE kongresszusokon rendszeresen szekcióelnök, a poszterszekciók szinte legendássá vált, hozzáértő, humánus, humoros levezetője. Mint a Magyar Biológiai Társaság vezetőségének tagja és a Felügyelő Bizottságának elnöke (1999-2014) komoly szerepet játszott a hazai szakmai közélet széleskörü fenntartásában. Mivel a Társaság a kutatókon kívül az érdeklődő tanárok, diákok számára is fontos találkozási pont volt, így a konferenciákon sokan ismerkedhettek meg egyes új tudományos eredményekkel.

1974-ben házasodott össze a szintén évfolyamtárs, botanikus MOLNÁR EDITtel, akivel kutatásaikban szintén sokat segítettek egymásnak, egy egész életen át. Nyugdíjasként viszszavonultan éltek, a saját maguk építette kertes házban Vácrátóton. JÁNOS sosem fogyott ki a tennivalókból, rendet tartott maga körül, a maga teremtette világban.

Köszönetnyilvánítás. Az anyag összeállításában és lektorálásában nyújtott segítségükért köszönetünket fejezzük ki elsősorban MoLNÁR EDITnek (akitől a fiatalkor adatai is származnak), és a nyugdíjban is jó barát OERTEL NÁNDORnak. HAJDÚ JÁNOS szintén fontos információkat és személyes emlékeket bocsátott a rendelkezésünkre, MECSNÓBER MELINDA pedig a Magyar Biológiai Társaság részéről gyüjtött számunkra adatokat. 


\title{
Farewell to biologist JÁNOS NOSEK (1949-2020)
}

\section{GÁBOR BAKONYI ${ }^{1 *}$ \& TAMÁS VÁSÁRHELYI ${ }^{2}$}

\author{
${ }^{1}$ Magyar Agrár- és Élettudományi Egyetem, Állattani és Ökológiai Tanszék, 2100 Gödöllö, Páter K. u. 1. \\ 21125 Budapest, Diós árok 16/II. \\ *E-mail: gaborbakonyi11@gmail.hu
}

\section{ÁLLATTANI KÖZLEMÉNYEK (2021) 106(1-2): 000-000.}

\begin{abstract}
We lost a great colleague and friend. JÁNOS NOSEK was a widely known hydrobiologist and popular person. He started his scientific career at the Hungarian Danube Research Station of the HAS (now: CER Institute of Aquatic Ecology) and worked there for 36 years. There he took part in investigations on periphyton and studied macroinvertebrate communities with NÁNDOR OERTEL for decades. Besides, he took part in some terrestrial ecological projects. He enjoyed the fieldwork, sampling, and photographing and was a master of quantitative data processing and data evaluation. Moreover, he was a patient and encouraging teacher who taught the MSc course "Biogeography" (Szent István University, Gödöllö) for two decades to the great satisfaction of the students. As the deputy director of the Ecological Research Institute from 1993-2004, he was a well-known scientist, leader or participant in several research projects. The total number of his scientific publications is 115. In addition, thanks to his excellent skills in English and German, he has translated several textbooks into Hungarian. He had an engaging personality and was a witty person in his communities. Nothing can bring JÁNOS back, but by this obituary, we would like to keep his memory alive in the zoological community of our country.
\end{abstract}




\section{NOSEK JÁNOS közleményeinek listája időrendben}

Ez a lista csak a tudományos könyveket, könyvrészleteket, publikációkat, egyetemi jegyzeteket és egyéb tudományos müveket tartalmazza. Nincsenek benne a konferencia kivonatok, népszerüsítő cikkek. A könyvfordítások az irodalomjegyzék után találhatók.

\section{A list of JÁNOS NOSEK's publications in chronological order}

This list contains only the scientific books, book chapters, publications, university textbooks and other scientific publications. Conference abstracts and articles of popularising purpose are omitted. Book translations are listed after the publications.

1. NoseK J. N. 1971. A sóféreg tömeges tenyésztése. Halászat XVII(64): 182-183.

2. BÁRdos Gy., Herman J., IFJ. NoseK J. \& KISS J. 1971. Reform vagy az oktatás forradalma. Felsöoktatási Szemle 20: 234-239.

3. NoseK J. \& OeRTel N. 1975. Bevonat vizsgálatok. (Investigations of periphyton). UNDP/WHO 'Hungary 3101' Project, Budapest-Göd, pp. 97-117.

4. NoseK J. 1975. Az eutrofizálódás modellezésének lehetősége. In: ÖLLÖS G. (szerk.): A vízellátás vízszerzési vonatkozásai és problémái. I. Szeminárium, Nyíregyháza, pp. 187-203.

5. Oertel N. \& Nosek J. 1976. Bevonat vizsgálatok (Investigations of periphyton). UNDP/WHO 'Hungary 3101' Project, Budapest-Göd, pp. 69-92.

6. NoseK J. 1976. Comparative analysis of some diversity functions under different conditions of sampling in sandy meadow. Acta Botanica Hungarica 22(3-4): 415-436.

7. FÁbián Gy., Précsényi I., Széky P., BAKonyi G., Molnár E., Melkó E. \& Nosek J. 1977. Stabil ${ }^{15} \mathrm{~N}$-izotóp áramlásának nyomonkövetése egy természetes homokpusztai gyep biocönózisában. ATE Közlemények 5-12.

8. Kozma E. \& NoseK J. 1977. Untersuchung des Zusammenhanges zwischen einigen Charakteristika des Donauwassers. (Danubialia Hungarica LXXX.) Annales Universitatis Scientiarum Budapestinensis De Roland Eötvös Nominatae - Sectio Biologica 18-19: 47-56.

9. Molnár E. N. \& NoseK J. N. 1979. Spatial processes in a grassland community. 1. Number of species and individuals, cover and biomass at the community level. Acta Botanica Academiae Scientiarum Hungaricae 25(3-4): 339-348.

10. Kozma E. \& NoseK J. 1979. Über die Zusammenhänge zwischen einigen Charakteristika des Donauwassers. 19. Arbeitstagung der IAD. Sofia, (Wissenschaftliche Kurzreferate), pp. 48-62.

11. Fekete G. Précsényi I., MolnÁr E. N. \& NoseK J. N. 1979. Szerkezet és müködés egy természetes növénytársulásban. Eredmények, problémák és perspektívák a Tece-homokpusztagyep kutatásában. MTA Biológiai Tudományok Osztályának Közleményei 22(3-4): 311-322.

12. FÁbián Gy. Précsényi I., SzéKy P., BAKonyi G., MolnáR E. N., Nosek J. N. \& Melkó E. 1978 1979. Investigations of ${ }^{15} \mathrm{~N}$ flow in a sandy grassland community. Annales Universitatis Scientiarum Budapestinensis De Roland Eötvös Nominatae - Sectio Biologica 20-21: 17-30.

13. Molnár E. N. \& NoseK J. N. 1980. Spatial processes in a grassland community. 2. Number of individuals, cover and biomass at population-level. Acta Botanica Academiae Scientiarum Hungaricae 26(3-4): 375-388. (TECE Studies 21.) 
14. Nosek J. N. \& Oertel N. 1980-1981. Zoologische Untersuchungen an Aufwüchsen in der Donau zwischen Rajka und Budapest. (Danub. Hung. C.). Annales Universitatis Scientiarum Budapestinensis De Roland Eötvös Nominatae - Sectio Biologica 22-23: 187-204.

15. NoseK J. N. \& BereCZKY M. Cs. 1981 Untersuchungen des Bestandstruktur des Ciliatenplanktons im Haupt- und in einem Nebenarm der Donau mit Hilfe der Produkt-Moment-Korrelations- und Pfadanalyse. Archiv für Protistenkunde 124: 173-192.

16. Nosek J. N., Bereczky M. Cs. \& Oertel N. 1982. Die Tiefenschichtung des Protozoenplanktons in der Donau. 23. Arbeitstagung der IAD, Wien (Wissenschaftliche Kurzreferate), pp. 116-119.

17. NoseK J. N. \& OERTEL N. 1983. A comparison of the periphytic communities in two sections of the Danube River. In: Wetzel R. G. (ed.):Periphyton of Freshwater Ecosystems. Developments in Hydrobiology, vol 17. Springer, Dordrecht, pp. 17-22.

18. NoseK J. N. \& BERECZKY M. Cs. 1983. Structural investigations of periphytic protozoan communities in three layers of the Danube River. II. The course colonization. In: WeTZEL R. G. (ed.):_Periphyton of Freshwater Ecosystems. Developments in Hydrobiology, vol 17. Springer, Dordrecht, pp. 55-58.

19. MolnÁr E. N., Nosek J. N. \& BAKonyi G. 1983. ${ }^{15} \mathrm{~N}$ dynamic in grassland communities I. Investigations of the plant subsystem in a sandy grassland. Acta Botanica Hungarica 29: 327-336.

20. BERECZKY M. Cs., OeRTEl N. \& NoseK J. N. 1983. Structural investigations of periphytic protozoan communities in three layers of the Danube River. In: Wetzel R. G. (ed.): Periphyton of Freshwater Ecosystems. Developments in Hydrobiology, vol 17. Springer, Dordrecht, pp. 49-54.

21. Bereczky, M. Cs., Oertel N. \& Nosek J. N. 1983. Die tiefenabhängige Entwicklung des Protozoenaufwuchses auf künstlichem Substrat in der Donau. Archiv für Hydrobiologie Supplementband 68(1): 37-62.

22. BAKONYI G. \& NoseK J. N. 1984. A ${ }^{15} \mathrm{~N}$-izotóphígitásos vizsgálatok egy módszertani kérdéséről I. Izotóptechnika 27: 23-33.

23. NoseK J. N. \& BAKONYI G. 1985. A ${ }^{15} \mathrm{~N}$-izotóphígitásos vizsgálatok egy módszertani kérdéséről II. Izotóptechnika 28: 42-51.

24. NoseK J. N. 1986. Spatial processes in a grassland community, III. Species-area relation, dominance-diversity curves, changes in the frequency and density of the species. Acta Botanica Hungarica 32: 61-78.

25. NoSEK J. N. 1986. Spatial processes in a grassland community, IV. Investigation of the spatial arrangement pattern by various indices. Acta Botanica Hungarica 32: 79-95.

26. NoseK J. N. 1986. Spatial processes in a grassland community, V. Frequency distributions of the species. Acta Botanica Hungarica 32: 97-108.

27. NoseK J. 1986. Egyszerü berendezés talajközelből történő fotografikus felvételezéshez. Botanikai Közlemények 73: 151-154.

28. BereczKy, M. Cs. \& NoseK J. N. 1986. Structural investigations of periphytic protozoan communities in three layers of the Danube river. III. Analysis of the saprobity relations. In: BereczKy M. Cs. (ed.): Advances in Protozoological Research. Symp. Biol. Hung.,Vol. 33. Akadémiai Kiadó, Budapest, pp. 217-224.

29. NoseK J. N. \& BereCZKY, M. Cs. 1988. Wirkung von Umweltfaktoren auf die ProtozoaPopulationen der Donau. 27. Arbeitstagung der IAD, Mamaia/Romania, (Wissenschaftliche Kurzreferate), pp. 401-404.

30. BereCzKy, M. Cs. \& NoseK J. N. 1988. Milieuspektrum-untersuchungen an Ciliaten-populationen der Donau. 27. Arbeitstagung der IAD, Mamaia/Romania, (Wissenschaftliche Kurzreferate), pp. $335-339$. 
31. Bereczky, M. Cs. \& Nosek J. N. 1992. Protozoológiai vizsgálatok Szob (1707fkm), Göd $(1669 \mathrm{fkm})$ és Lórév (1559fkm) térségében. XXXIV. Hidrobiológus Napok pp. 12-14.

32. Abaffyné Bothár A., Bancsi I., CsÁnyi B., Bereczky M. CS., DÉvai I., Gulyás P., Kertész Gy., Kiss Keve T., Kollár Gy., Németh J., Nosek J. N., Padisák J., Pomogyi P., Schmidt A., TEVAnNé BARTAlis É., VASA F., Vörös L. \& WitTner I. 1992. Állásfoglalás a hidrobiológiai vízminősítés helyzetéröl és rövidtávú feladatairól. Acta Biologica Debrecina - Supplementum Oecologica Hungarica 4: 187-201.

33. BereCzKy, M. Cs. \& NoseK J. N. 1993. The influence of ecological factors on the abundance of different ciliated Protozoa populations in the Danube River. I. Investigation of the ecological amplitude. Acta Protozoologica 32(1): 1-16.

34. BereczKy, M. Cs. \& Nosek J. N. 1994. Composition and feeding spectrum of Protozoa in the River Danube, with particular reference to planktonic Ciliata. Limnologica 24: 23-28.

35. BereCzKy, M. Cs. \& NoseK J. N. 1994. Protozoologische Untersuchungen im CikolaNebenarmsystem der Kleiner Schüttinsel. Limnologische Berichte Donau 1994, pp. 45-48.

36. NoseK J. N. \& BeRECZKY M. Cs. 1995. The effects of some environmental factors on protozoa populations of the River Danube. Tiscia (Szeged) 28: 29-36.

37. Bereczky, M. Cs. \& Nosek J. N. 1995. Protozoological investigations in the side-arm system Szigetköz of the River Danube (1991-1992). Opuscula Zoologica (Budapest) 27-28: 123-135.

38. NoseK J. N. \& BERECZKY M. Cs. 1996. Influence of environmental factors on Protozoa populations in the River Danube. Journal of Eukaryotic Microbiology 43(1) (Suppl. the Soc. of Prot.): 101.

39. NoseK J. N. 1996. Untersuchungen der wirbellosen Wassermakrofauna in der Kleinen Schüttinsel (Szigetköz). Limnologische Berichte Donau 1996 1: 255-260.

40. Nosek J. \& Molnár Zs. 1997. Állóvizek In: Fekete G., Molnár Zs., Horváth F. (szerk.): A magyarországi élöhelyek leirása, határozója és a Nemzeti Élöhely-Osztályozási Rendszer. Magyar Természettudományi Múzeum, Budapest, pp. 238-240.

41. Nosek J. 1997. Folyóvizek. In: Fekete G., MolnáR Zs., HorvÁth F. (szerk.): A magyarországi élöhelyek leirása, határozója és a Nemzeti Élöhely-Osztályozási Rendszer. Magyar Természettudományi Múzeum, Budapest, pp. 236-237.

42. BereCZKY, M. Cs. \& NoseK J. N. 1997. Study on benthic ciliates from the abandoned main channel of River Danube between Rkms 1846-1812. Limnologische Berichte Donau 1997: $317-$ 322.

43. BercziK Á. \& NoseK J. N. 1997. Gerinctelen állatok kutatása a Balatonon. In: SALÁNKi J. \& Nemcsók J. (szerk.): A Balatonkutatás eredményei 1981-1996. Az MTA Veszprémi Területi Bizottsága és a Miniszterelnöki Hivatal Balatoni Titkársága, Veszprém, pp. 137-172.

44. Kiss K. T., NoseK J. \& Kremmer L. 1998. Diurnal change of phytoplankton, some physical and chemical components in the River Danube near Budapest (Hungary). Verhandlungen der Internationale Vereinigung für Theoretische und Angewandte Limnologie 26(3): 1041-1044.

45. Oertel N. \& Nosek J. 2000. Bioindikáció vízi gerinctelenekkel a Dunában. 1. Bevezetés - elvi és módszertani kérdések. Hidrológiai Közlöny 80(5-6): 336-338.

46. NoseK J. \& Oertel N. 2000. Bioindikáció vízi gerinctelenekkel a Dunában. 2. A makrofauna téridőbeli mintázata. Hidrológiai Közlöny 80(5-6): 333-335.

47. NoseK J. 2000. Macroinvertebrate studies at the Hungarian Danube section 2. Spatial pattern of macroinvertebrate communities in 1998. International Association of the Danube Research Osijek, 33: 263-270. 
48. Bakonyi G., Posta K., Nagy P., FÁbián M., Kiss I. \& NoseK J. 2000. Szárazság és nitrogén mütrágyázás hatása kukorica és gyep endomikorrhizáira, valamint a szabadonélő fonálférgekre barna erdőtalajon. Agrokémia és Talajtan 49: 479-490.

49. Oertel N., Nosek J. \& ANDrikovics S. 2001. Bioindikáció vízi gerinctelenekkel a Dunában. 5. Mesterséges alzatok alkalmazása a kolonizáció vizsgálata során. Hidrológiai Közlöny 81(5-6): $438-440$.

50. Oertel N. \& NoseK J. 2001. Fundamental and methodological problems of biomonitoring with macroinvertebrates in large rivers. In: Proceedings of XI International Symposium on Bioindicators, Problems of Today in Bioindication and Biomonitoring. Syktyvkar, Komi Republic, Russia, pp. 328-329.

51. Nosek J., Oertel N. \& ANDrikovics S. 2001. Bioindikáció vízi gerinctelenekkel a Dunában. 6. A domináns szervezetek kolonizációjának menete. Hidrológiai Közlöny 81(5-6): 434-437.

52. ANDrikovics S., KisS O., Nosek J. \& Oertel N. 2001. Bioindikáció vízi gerinctelenekkel a Dunában, 7. A fénycsapdák alkalmazási lehetősége a gerinctelen makrofauna feltárásában. Hidrológiai Közlöny 81(5-6): 314-315.

53. NoseK J. 2002. Gerinctelen makrofauna kutatások. In: FeKete G., Kiss K. T., KovÁCSNÉ LÁNG E., Kun A., Nosek J. \& RÉvÉsz A. (szerk.): A Magyar Tudományos Akadémia Ökológiai és Botanikai Kutatóintézete 50 Éve, 1952-2002. MTA Ökológiai és Botanikai Kutatóintézete, Vácrátót, pp. 351-371.

54. NoseK J. N. 2002. Macroinvertebrate studies at the Hungarian Danube section 4. The colonization dynamics of macroinvertebrates on different substrates. Limnological Reports 34: 317-326.

55. Fekete G., TöröK K., Kovács-LÁng E., Kiss K. T. \& NoseK J. (eds) 2002. Institute of Ecology and Botany of the Hungarian Academy of Sciences, 1952-2002. Vácrátót, 42 pp.

56. Fekete G., Kiss K. T., Kovácsné LÁng E., Kun A., Nosek J. \& Révész A. (szerk.) 2002. A Magyar Tudományos Akadémia Ökológiai és Botanikai Kutatóintézete 50 Éve, 1952-2002. MTA Ökológiai és Botanikai Kutatóintézete, Vácrátót, 460 pp. + 16 o. fotó melléklet.

57. Bakonyi G., Posta K., Kiss I., Fábián M., Nagy P. \& Nosek J. N. 2002. Density-dependent regulation of arbuscular mycorrhiza by Collembola. Soil Biology \& Biochemistry 34(5): 661-664.

58. Oertel N. \& NoseK J. 2003. Bioindikáció vízi gerinctelenekkel a Dunában. 8. Mesterséges alzatok biomonitorozásra való alkalmazhatósága. Hidrológiai Közlöny 83(1-12. Klnsz.): 101-104.

59. Nosek J., Oertel N. \& Tóth B. 2003. Bioindikáció vízi gerinctelenekkel a Dunában. 9. Mennyiségi mintavételek összehasonlító vizsgálata. Hidrológiai Közlöny 83(1-12. Klnsz.): 98-100.

60. Oertel N. \& NoseK J. 2004. Veränderungen der Makroinvertebratenbiozönose im Bereich der Donau-Schüttinsel $=$ Changes of the macroinvertebrate fauna in the Szigetköz. Donau Aktuell 9 : $1-4$.

61. NoseK J. \& Oertel N. 2004. Makrogerinctelenek biodiverzitás vizsgálata a magyar Dunaszakaszon I. Bevezetés és előzetes eredmények. Hidrológiai Közlöny 84(5-6): 104-107.

62. Oertel N. \& Nosek J. 2004. Comparative analysis of quantitative macroinvertebrate sampling techniques. Limnological Reports 35: 173-180.

63. NoSEK J. \& TURCSÁNYi G. (szerk.) 2004. A biogeográfia alapjai. Egyetemi jegyzet. SZIE Környezet- és Tájgazdálkodási Intézet, Gödöllö, 107 pp.

64. NoseK J. 2004. Az állatföldrajz alapjai. In: NoseK J. \& TurCsánYI G. (szerk.): A biogeográfia alapjai. Egyetemi jegyzet, SZIE Környezetgazdálkodási Intézet, Gödöllő, pp. 59-107.

65. VÁSÁRHELYI T., BAKONYI G. \& NOSEK J. 2005. A vízipoloska-fauna évtizedes léptékủ változása a Szigetközben. Acta Biologica Debrecina - Supplementum Oecologica Hungarica 13: 249-258. 


\section{BÚCSÚ NOSEK JÁNOS BIOLÓGUSTÓL}

66. Tóth B., Nosek J. \& Oertel N. 2005. A szervesanyag és lebegőanyag koncentrációjának hosszútávú változása a Dunában. Hidrológiai Közlöny 85(6): 152-154.

67. Oertel N., Nosek J. \& ANDRikovics S. 2005. A magyar Duna-szakasz litorális zónájának makroszkópikus gerinctelen faunája (1998-2000). Acta Biologica Debrecina - Supplementum Oecologica Hungarica 13: 159-185.

68. OERTEL N. \& NoSEK J. 2005. Makroszkopikus vízi gerinctelen állatok vizsgálata a Dunában. In: TÖRÖK K. \& KovÁCs-LÁNG E. (szerk.): Válogatás Az MTA Ökológiai és Botanikai Kutatóintézete Kutatási Eredményeiböl, Vácrátót, pp. 23-26.

69. NoseK J. 2005. A vízi gerinctelen makrofauna változása a Szigetközben az utóbbi tíz évben. Hidrológiai Közlöny 85(6): 105-107.

70. Csabai Z., Nosek J. \& Oertel N. 2005. Aquatic beetle fauna of Béda-Karapancsa Landscape Protection Area, South Hungary (Coleoptera: Hydradephaga, Hydrophiloidea) = A BédaKarapancsa Tájvédelmi Körzet vízibogár faunája (Coleoptera: Hydradephaga, Hydrophiloidea). Acta Biologica Debrecina - Supplementum Oecologica Hungarica 13: 29-35.

71. Tóth B., Nosek J. \& Oertel N. 2006. Spatial and temporal changes in the benthic organic matter at the depositive and erosive zones of the Hungarian Danube. In: Proceedings of the 36th International Conference of IAD: 50 Years International Association for Danube Research, pp. 404-409.

72. Tóth B., NoseK J. \& Oertel N. 2006. A mederanyag szemcseméret szerinti frakcióinak és szervesanyag-tartalmának mélységbeli változása a Duna középső szakaszán. Hidrológiai Közlöny 86(6): 123-125.

73. Puky M., NoSEK J. \& TóTH B. 2006. Long-term changes in the clutch number of a Rana dalmatina population at the Danubian Floodplain at Göd, north of Budapest, Hungary. In: Proceedings of the 36th International Conference of IAD: 50 Years International Association for Danube Research, pp. 307-311.

74. Oertel N. \& NoseK J. 2006. Makroszkopikus gerinctelen közösségeken alapuló biotikus indexek összehasonlítása. Acta Biologica Debrecina - Supplementum Oecologica Hungarica 14: 185194.

75. Oertel N. \& NoseK J. 2006. Comparative analysis of biotic indices based on macroinvertebrate communities. In: Proceedings of the 36th International Conference of IAD: 50 Years International Association for Danube Research, pp. 270-274.

76. OeRtel N. \& NoSEK J. 2006. Macroinvertebrate studies at the Hungarian reach of the River Danube. In: Proceedings of the 36th International Conference of IAD: 50 Years International Association for Danube Research, pp. 275-279.

77. OERTEL N. \& NoSEK J. 2006. Investigation of macroinvertebrates in the River Danube. In: TÖRÖK K. \& KovÁcs-LÁng E. (eds): Recent Research Results Supporting Sustainability. Institute of Ecology and Botany of the Hungarian Academy of Sciences, Vácrátót, pp. 23-26.

78. Oertel N. \& NoseK J. N. 2006. Sampling of macroinvertebrates by artificial substrates in the River Danube (Hungary). Verhandlungen der Internationale Vereinigung für Theoretische und Angewandte Limnologie 29(4): 1762-1766.

79. Nosek J. \& Oertel N. 2006. Section types in the Hungarian Reach of the River Danube according to the Macroinvertebrate Communities. In: Proceedings of the 36th International Conference of IAD: 50 Years International Association for Danube Research pp. 265-269.

80. Nosek J. N. \& Oertel N. 2006. A magyar Duna szakaszjellege a makroszkópikus gerinctelen társulások alapján. Acta Biologica Debrecina - Supplementum Oecologica Hungarica 14: 175184. 
81. NoSEK J. \& BAKONYi G. 2006. A nitrogénáramlás nyomon követése életközösségekben: a ${ }^{15} \mathrm{~N}$ dúsításos módszertől a természetes ${ }^{15} \mathrm{~N}$-arányokon alapuló eljárásig. In: MoLNÁR E. (szerk.) Kutatás, oktatás, értékteremtés. A 80 éves Précsényi István köszöntése MTA, ÖBKI, Vácrátót, pp. 53-70.

82. Csabai Z. \& NoseK J. 2006. Aquatic beetle fauna of the Szigetköz, NW Hungary (Coleoptera: Hydradephaga, Hydrophiloidea). Acta Biologica Debrecina - Supplementum Oecologica Hungarica 14: 77-90.

83. Csabai Z. \& NoSEK J. 2006. Aquatic beetle fauna of Gemenc Landscape Protection Area, South Hungary (Coleoptera: Hydradephaga, Hydrophiloidea). Acta Biologica Debrecina Supplementum Oecologica Hungarica 14: 67-76.

84. Bódis E. NoseK J. N. \& Oertel N. 2006. Mussel fauna (Corbiculidae, Dreissenidae, Sphaeriidae) in the watersystem of the Hungarian Danube. In: Proceedings of the 36th International Conference of IAD: 50 Years International Association for Danube Research pp. 219-223.

85. BÓDIS E. \& NoSEK J. 2006. Makrogerinctelenek biodiverzitás-vizsgálata a magyar Dunaszakaszon III. A Szigetköz kagylófaunája. Hidrológiai Közlöny 86(6): 21-23.

86. ANDrikovics S., NoSEK J. \& OeRTEl N. 2006. Szitakötő (Odonata) lárvavizsgálatok a Szigetközben. Acta Biologica Debrecina - Supplementum Oecologica Hungarica 14: 9-19.

87. Andrikovics S., Nosek J. \& Oertel N. 2006. Kérész (Ephemeroptera) lárvavizsgálatok a Szigetközben. Acta Biologica Debrecina - Supplementum Oecologica Hungarica 14: 21-30.

88. VÁsÁrhelyi T., Nosek J., BAKonyi G. \& Oertel N. 2007. Adatok a Ráckevei- (Soroksári-) Duna vízi- és vízfelszíni poloska-, valamint vízibogár-faunájához (Heteroptera: Nepomorpha, Gerromorpha, Coleoptera: Hydradephaga, Hydrophilodea). Acta Biologica Debrecina Supplementum Oecologica Hungarica 16: 221-229.

89. Sipkay Cs., Nosek J., Oertel N., VAdAdi-FülÖP Cs. \& Hufnagel L. 2007. Klímaváltozási szcenáriók elemzése egy dunai Copepoda-faj szezonális dinamikájának modellezése alapján. Klíma 21 Füzetek 49: 80-90.

90. Oertel N., Nosek J. \& Ponyi J. 2007. Meiofauna-kutatások a Duna hiporheális régiójában. Acta Biologica Debrecina - Supplementum Oecologica Hungarica 16: 175-186.

91. Oertel N. \& Nosek J. 2007. Müködési adatok. In: Nosek J. \& Oertel N. (szerk.): A Dunának, mely múlt, jelen s jövendö.... 50 éves az MTA Magyar Dunakutató Állomása (1957-2007). Szemelvények az Állomás tudományos eredményeiből. MTA ÖBKI - MDÁ, Göd-Vácrátót, pp. $147-167$.

92. Nosek J. N., VÁsÁrhelyi T., BAKonyi G. \& Oertel N. 2007. Spatial pattern of water bugs (Nepomorpha, Gerromorpha) at different scales in the Szigetköz (Hungary). Biologia (Bratislava) 62(3): 345-350.

93. Nosek J. \& Oertel N. (szerk.) 2007. A Dunának, Mely Múlt, Jelen s Jövendő... 50 éves az MTA Magyar Dunakutató Állomása (1957-2007). Szemelvények az Állomás tudományos eredményeiből. MTA ÖBKI - MDÁ, Göd-Vácrátót, 190 pp.

94. NOSEK J. 2007. Gerinctelen makrofauna kutatások a Duna magyarországi szakaszán. In: NOSEK J. \& Oertel N. (szerk.): A Dunának, mely múlt, jelen s jövendö.... 50 éves az MTA Magyar Dunakutató Állomása (1957-2007). Szemelvények az Állomás tudományos eredményeiből. MTA ÖBKI - MDÁ, Göd-Vácrátót, pp. 65-81.

95. NoSEK J. N. 2007. Contribution to the macroinvertebrate fauna of the Hungarian Danube I. Introduction, sampling sites and methods. Folia Historico-Naturalia Musei Matrensis 31: 15-41.

96. Csabai Z., NoseK J. N. \& Oertel N. 2007. Contribution to the macroinvertebrate fauna of the Hungarian Danube. II. Aquatic beetles (Coleoptera: Hydradephaga and Hydrophiloidea). Folia Historico-Naturalia Musei Matraensis 31: 139-147. 


\section{BÚCSÚ NOSEK JÁNOS BIOLÓGUSTÓL}

97. Tóth B., Nosek J. \& Oertel N. 2008. Composition and dynamics of benthic organic matter in the Middle Danube Section. Archiv für Hydrobiologie Supplementband Large Rivers 18/1-2 (Arch. H. Suppl. 166): 257-270.

98. Tóth B., BóDis E., NoseK J. \& Oertel N. 2008. Dynamics of the suspended particulate organic matter in the middle Danube section at Göd (1669 river km). In: Proc. 37th International Conference of IAD. 29. oct.-01. nov. 2008. Chisinău, Moldova, pp. 237-243.

99. SipKay Cs., Horváth L., Nosek J., Oertel N., VADAdi-FülÖP Cs., FarKas E., DréGelyi-Kiss Á. \& Hufnagel L. 2008. Analysis of climate change scenarios based on modelling of the seasonal dynamics of a Danubian Copepod species. Applied Ecology and Environmental Research 6(4): 101-109.

100. Nosek J. \& OeRtel N. 2008. Similarity patterns of macroinvertebrate communities in the Hungarian Danube and adjecent wetlands (Szigetköz and Gemenc). Archiv für Hydrobiologie Supplementband Large Rivers 18/1-2 (Arch. H. Suppl.166): 243-256.

101. BóDis E., Nosek J., Oertel N. \& Tóth B. 2008. A kagylófauna longitudinális eloszlása a Duna vízrendszerében. Acta Biologica Debrecina - Supplementum Oecologica Hungarica 18: 9-20.

102. Bódis E., NoseK J. \& Oertel N. 2008. Spatio-temporal pattern of mussels (Corbiculidae, Dreissenidae, Sphaeriidae) in the waters of the Hungarian Danube. Archiv für Hydrobiologie Supplementband Large Rivers 18/1-2 (Arch. H. Suppl.166.): 293-308.

103. Tóth B., Bódis E., NoseK J. \& Oertel N. 2009. Dynamics of the suspended organic matter in the Middle Danube section at Göd (1669 River Km). In: Proc. 37th International Conference of IAD. 29. oct.-01. nov. 2008. Chisinău, Moldova pp. 174-178.

104. NoseK J., Oertel N., Bódis E. \& Tóth B. 2009. A bentikus szervesanyag és a makrogerinctelen társulások tér- és időbeli változása a Duna Kismaros (1688 Fkm) és Göd (1668 Fkm) közötti szakaszán. Acta Biologica Debrecina - Supplementum Oecologica Hungarica 20: 165-179.

105. BóDis E., NoseK J., Oertel N. \& TÓth B. 2009. Longitudinal dispersion of mussel fauna in a second order stream - Danube continuum in North Hungary. In: Proc. 37th International Conference of IAD. 29. oct.-01. nov. 2008. Chisinău, Moldova, pp. 97-102.

106. Bódis E., Borza P., Oertel N., Nosek J. \& Tóth B. 2010. Dunai makrogerinctelenmintavételek tanulságai a Gödi-Sziget térségében. Acta Biologica Debrecina - Supplementum Oecologica Hungarica 21: 139-152.

107. FÜleP T. \& NoseK J. N. 2010. Contribution to the macroinvertebrate fauna of the Hungarian Danube VI. Triclads (Platyhelminthes: Tricladida). Folia Historico-Naturalia Musei Matraensis 34: 5-9.

108. Borza P., Nosek J. \& Oertel N. 2010. Contribution to the macroinvertebrate fauna of the Hungarian Danube. V. Folia Historico-Naturalia Musei Matraensis 34: 17-27.

109. TÓth B., Bódis E., NoseK J. \& Oertel N. 2011. A bentál strukturális és funkcionális elemei a Duna vízrendszerében I. Mederanyag és szervesanyag. Hidrológiai Közlöny 91(6): 101-104.

110. Oertel N., Nosek J., Bódis E., Borza P. \& Tóth B. 2011. A bentál strukturális és funkcionális elemei a Duna vízrendszerében 2. A meio- és makrogerinctelen társulások. Hidrológiai Közlöny 91(6): 65-68.

111. Bódis E., Nosek J., Oertel N., Tóth B., Hornung E. \& Sousa R. 2011. Spatial distribution of bivalves in relation to environmental conditions (Middle Danube Catchment, Hungary). Community Ecology 12(2): 210-219.

112. Bódis E., Nosek J., Oertel N., Tóth B. \& Fehér Z. 2011. A comparative study of two Corbicula morphs (Bivalvia, Corbiculidae) inhabiting River Danube. International Review of Hydrobiology 96(3): 257-273. 
113. BóDis E., NoseK J., Oertel N. \& Tóth B. 2011. A bentál strukturális és funkcionális elemei a Duna vízrendszerében. 3. A kagylófauna térbeli mintázata a környezeti változók függvényében. Hidrológiai Közlöny 91(6): 29-32.

114. Hufnagel L., Gimesi L., Dede L., Sipkay Cs., VAdadi-FülöP Cs., Verasztó Cs., Gergócs V., Kiss K. T., Oertel N. \& NoseK J. 2012. Megfigyelt cönológiai mintázatok monitoring és térbeli adatbázisok alapján. In: HuFNÁGEL L. \& SIPKAY Cs. (szerk.): A klímaváltozás hatása ökológiai folyamatokra és közösségekre. Budapesti Corvinus Egyetem, Budapest, pp. 334-447.

115. Bódis E., Sipkay Cs., Tóth B., Oertel N., Nosek J. \& Hornung E. 2012. Spatial and temporal variation in biomass and size structure of Corbicula fluminea in Middle Danube catchment, Hungary. Biologia Bratislava 67(4): 739-750.

\section{Szak- és tudományos ismeretterjesztő könyvfordítások Book translations}

Southwood T. R. E. 1984. Ökológiai módszerek - különös tekintettel a rovarpopulációk tanulmányozására. Mezőgazdasági Kiadó, Budapest, 314 pp.

KERROD R. 1990. Az állatvilág enciklopédiája - Velünk élö állatok. Helikon Kiadó, Budapest, 95 pp.

Slater P. J. B. 1992. Az állatok viselkedése. Helikon Kiadó, Budapest, 152 pp.

Stidworthy J. 1992. Az állatvilág enciklopédiája - Alsóbbrendü állatok. Helikon Kiadó, Budapest, $95 \mathrm{pp}$.

KERROD R. 1993. Az állatvilág enciklopédiája - Föemlösök, rovarevők, szilás cetek. Helikon Kiadó, Budapest, 95 pp.

Kerrod R. 1994. Az állatvilág enciklopédiája - A Föld állatai. Helikon Kiadó, Budapest, 96 pp.

DiXon D. 1995. Az állatvilág enciklopédiája - Az állati evolúció. Helikon Kiadó, Budapest, 95 pp.

BuRNIE D. 2002. Állatok, Bevezetés, élőhelyek. GABO Kiadó, Budapest, pp. 12-81. 